\title{
Simulation of the Effects of Climate Change on Yield of Maize in Zimbabwe
}

\author{
기후변화가 짐바브웨 옥수수 수확량에 미치는 영향 모의 \\ Nkomozepi Temba* - Chung, Sang-Ok ${ }^{*,+}$ \\ 은코모제피 템바 - 정상옥
}

\begin{abstract}
기후변화는 에너지 수지와 물 수지의 변화를 초래하여 육상 생물권에 영향을 미칠 것이다. 기온과 강수량의 변화와 대기중의 탄산가스 농도 변화는 작물의 생육환경을 크게 변화시킬 것이다. 본 연구에서는 $\mathrm{FAO}$ AquaCrop 모형을 이용하여 기온과 강수량 의 변화와 대기중 탄산가스 농도의 변화가 짐바브웨의 옥수수 수확량에 미치는 영향을 분석하였다. 미래 기후 값은 $\mathrm{HadCM} 3$ 모 형 예측 값을 change factor 기법으로 상세화 하였다. 배출 시나리오는 A2와 B2를 선정하였으며 시간대는 2020s, 2050s 및 2080s 의 30 년 기간을 선정하였다. 기준작물 증발산량은 Penman-Monteith 식으로 산정하였다. 관개용수 공급이 충분한 것으로 가정하고 전통적인 보충관개를 실시하였을 때 기준년도 (1970s)에 비해 옥수수 증발산량은 최대 $26 \%$, 옥수수 잠재 수확량은 최대 $93 \%$ 까지 증가할 것으로 예측되었으며 물의 생산성은 최대 $53 \%$ 까지 증가할 것으로 예측되었다.
\end{abstract}

Keywords: AquaCrop; climate change; yield; maize

\section{Introduction}

Increasing atmospheric greenhouse gas concentrations are responsible for the changes observed in climate over time. The impacts associated with climate change lie in the interaction of several systems with many variables that must be collectively considered. The combined effect of temperature increases and rainfall reductions exacerbate stress on water resources that are essential for crop growth. Nkomozepi and Chung (2011) assessed the effects of climate change on the net irrigation water requirement in major maize production areas in Zimbabwe. The study predicted significant increases in the net irrigation water requirement of up to 121 percent as a result of increasing temperature and decreasing rainfall. Carbon dioxide $\left(\mathrm{CO}_{2}\right)$ levels have been projected to increase to $611 \mathrm{ppm}$ and $836 \mathrm{ppm}$ for the SRES B2 and A2 respectively by 2100 (IPCC, 2001). Although the photosynthetic mechanism for

\footnotetext{
* Department of Agricultural Engineering, Kyungpook National University

$\dagger \quad$ Corresponding author Tel.: +82-53-950-5734

Fax: +82-53-950-6752

E-mail: sochung@knu.ac.kr
}

2011년 4월 4일 투고

2011년 5월 19일 심사완료

2011년 5월 23일 게재확정
$\mathrm{C}_{4}$ plants at elevated atmospheric $\mathrm{CO}_{2}$ remains largely uncertain (Chun et al., 2011), interactions of $\mathrm{CO}_{2}$ with limiting factors such as water and nitrogen are known to be capable of strongly modulating growth responses in crop plants.

In recent studies, Chung (2010) projected the potential rice yield in South Korea to have doubled by the 2080s as a result of climate change using outputs from the ECHO-G general circulation model (GCM) and the FAO AquaCrop model. The AquaCrop model was used to simulate soybean crop growth, development and yield over a 7-year period (1995-2001) on a 5 ha plot in India and good agreement was observed between measured and simulated values despite significant rainfall variations (Studeto et al., 2009). In California, data sets from six years of maize field experiments were used to parameterize and test the AquaCrop model. The model accurately predicted biomass and grain yield (Hsiao et al., 2009).

AquaCrop is a water-driven model and it is used as a decision support tool in the planning and analysis of different seasons and locations and scenarios. It simulates the variation in attainable crop biomass and harvestable yield in response to variation in soil moisture in the root 
zone.

The objective of this study is to find the effects of climate change on maize yields in the northern and southern regions of Zimbabwe for this century under full irrigation using the AquaCrop model.

\section{Materials and methods}

\section{Study area}

Agriculture in Zimbabwe is spread across a variety of natural agro-ecological regions that range from areas of high rainfall and productivity in the north to areas of extremely low productivity where rainfall is sparse and variable in the south (Fig. 1). Average national annual rainfall is $657 \mathrm{~mm}$, but it ranges from over $1,000 \mathrm{~mm}$ in the north eastern highlands to around $300-450 \mathrm{~mm}$ in the lowveldt in the south. The landscape in southern Zimbabwe is relatively flat, interspersed with rounded granite mountains. The north is mostly hilly and mountainous with valleys that are used for agriculture and mining. The groundwater table lies well below the rooting depth in most maize farming areas so capillary rise is not expected to influence the water content in the root zone (Wurzel, 1987). Zimbabwe has a single rainy season that occurs in the southern hemisphere summer. Maize is the primary staple crop, a feed commodity and a significant bio-ethanol energy source and it occupies about half of the agricultural land in Zimbabwe (Phillips et al., 1997).

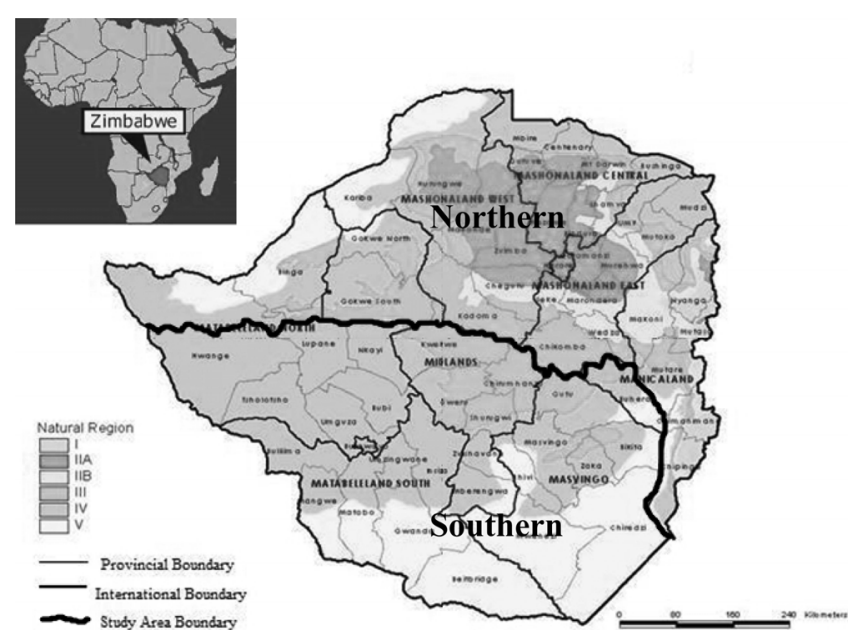

Fig. 1 Map of Zimbabwe's northern and southern regions

\section{Climate data collection}

In this study, climate change is defined as change in the long-term averages in precipitation, mean temperature, wind speed, relative humidity and solar radiation. The change factor procedure was used in this study and the illustrations of this method are presented in detail in Nkomozepi and Chung (2011). The procedure involves 3 steps, firstly, establishment of long term baseline climatology data (1961-1990). Secondly, changes in the equivalent variable are calculated for the GCM grid box closest to the target site. Thirdly the change suggested by the GCM for a particular time slice is applied to each monthly average in the baseline time series (Diaz-Nieto and Wilby, 2005; Ahn et al., 2009; Nkomozepi and Chung, 2011).

Climate data was derived from the Hadley Centre Coupled Model (HadCM3) outputs for IPCC SRES A2 and B2 scenarios (Gordon et al., 2000). The A2 scenario family describes a very heterogeneous world where the underlying theme is self-reliance and preservation of local identities. Fertility patterns across regions converge very slowly, which results in continuously increasing global population. Economic development is primarily regionally oriented and economic growth and technological changes are more fragmented and slower than in other storylines. The B2 scenario family describes a world in which the emphasis is on local solutions to economic, social, and environmental sustainability. It is a world with continuously increasing global population at a rate lower than A2, intermediate levels of economic development, and less rapid and more diverse technological change than in the $\mathrm{B} 1$ and $\mathrm{A} 1$ storylines. While the B2 is also oriented toward environmental protection and social equity, it focuses on local and regional levels. SRES A2 and B2 scenarios were selected for this study, because they represent regional emphasis with economic and environmental emphasis which might be suitable for Zimbabwe and for consistency with related studies e.g. Chung et al. (2011) and Nkomozepi and Chung (2011).

In southern Africa, weather data are often from a very sparse meteorological network, incomplete and/or not always readily available to enable relatively accurate climate impact assessment (Unganai and Kogan, 1998). A 10' by 10' 
latitude / longitude climate dataset assembled by IWMI for the period 1961-1990 (New et al., 2002) was therefore extracted and adopted as the baseline climatology for the study area. Data sets from IWMI (baseline) and from the HadCM3 model (future projections) were used to derive climate data for the future time periods i.e. 2020s, 2050s and 2080s.

\section{Atmospheric $\mathrm{CO}_{2}$ concentration}

The global atmospheric concentration of $\mathrm{CO}_{2}$ is expected to increase from $331 \mathrm{ppm}$ in the 1970s to 836 (A2) and 611 ppm (B2) by 2100 as shown in Fig. 2 (IPCC, 2001). $\mathrm{CO}_{2}$ concentration is commonly required as a direct input to models of plant growth, since it can affect both the growth and water use of many plants through its firstorder effect on photosynthesis and stomatal conductance. As well as having direct effects on vegetation and biomass, it is also the major greenhouse gas associated with global climate change. $\mathrm{CO}_{2}$ is well mixed in the atmosphere, so observations of concentrations from a single site are adequate for most impact applications, and global values from the Bern model (IPCC, 2001) were used in this study.

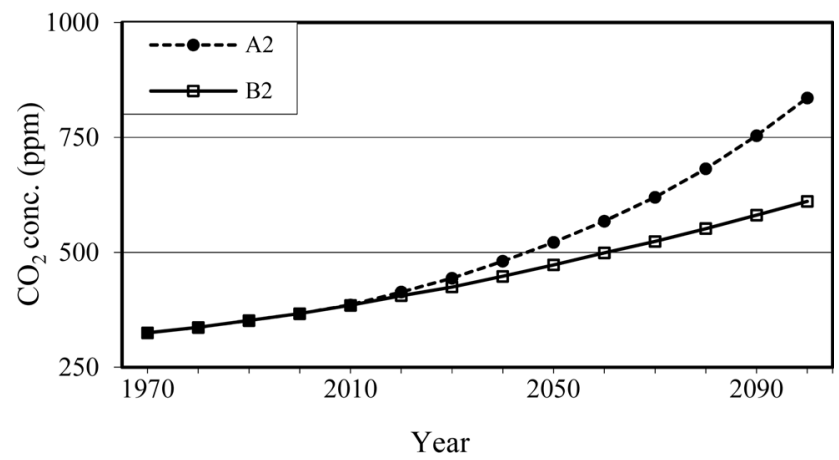

Fig. 2 Future atmospheric $\mathrm{CO}_{2}$ concentrations, Bern model (IPCC, 2001)

\section{Crop yield model}

When forecasting for regional crop yields, simplified descriptions of reality such as homogenous crop fields with defined thematic boundaries, internal characteristics and external driving variables with an apparent absence of uncertainty are used. Maize yield can be classified into potential, attainable and actual yield. The maximum obtainable yield (potential yield) is influenced by defining factors i.e. $\mathrm{CO}_{2}$, radiation, temperature and crop features. The attainable yield is a fraction of the potential yield as influenced by limiting factors such as water and nutrient availability. The actual yield refers to the fraction of attainable yield as influenced by reducing management factors such as weeds, pests, diseases and pollutants. AquaCrop was used to simulate potential yields in this study.

AquaCrop model has a structure that overarches the soil-plant-atmosphere continuum. It includes the soil, with its water balance, the plant, with its development, growth and yield processes, and the atmosphere, with its thermal regime, rainfall, irrigation, evaporative demand and carbon dioxide concentration. Additionally, some management aspects are explicitly considered, as they will affect the soil water balance, crop development and therefore crop yield. The functional relationships between the different model components are depicted in Fig. 3 .

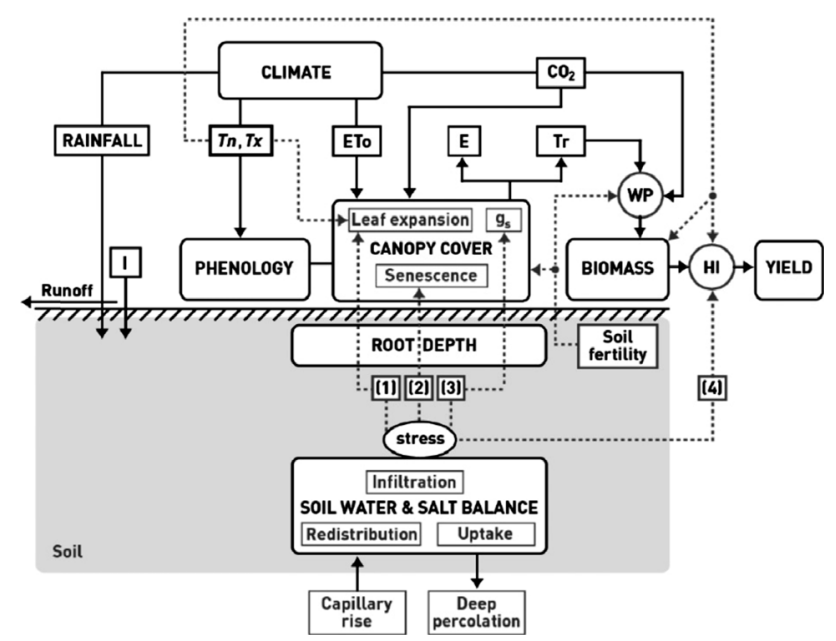

Fig. 3 Schematics of AquaCrop showing the main components of the soil-plant-atmosphere continuum (Raes et al., 2010)

The root zone can be considered as a reservoir as with incoming and outgoing water fluxes at the boundaries of the root zone by means of a soil water balance. For the soil profile explored by the root system, the model performs a water balance that includes the processes of runoff, infiltration, redistribution, deep percolation, capillary 
rise, uptake, evaporation, and transpiration. AquaCrop uses the dual crop coefficient approach to determine ET:

$$
E T=\left(K_{c b}+K_{e}\right) \cdot E T_{o}
$$

where $E T$ is crop evapotranspiration, $K_{c b}$ is the crop transpiration coefficient, $K_{e}$ is evaporation coefficient and $E T_{o}$ is the reference $E T$. The model was developed from concepts of seasonal or stage yield responses to water as described in Doorenbos and Kassam (1979). The model separates $E T$ into evaporation (E) and transpiration (Tr) to avoid the confounding effect of the non-productive consumptive use of water (evaporation) especially during periods of incomplete ground cover. The biomass production as a function of transpiration is one of the core of the model (Raes et. al., 2010):

$$
B=W P \cdot \sum T r
$$

where $B$ is the biomass production, $W P$ is the water productivity parameter ( $\mathrm{kg}$ of biomass per $\mathrm{m}^{2}$ and per $\mathrm{mm}$ of water transpired) and $T r$ is the crop transpiration. In AquaCrop, the yield is separated from total biomass by the inclusion of the harvest index (HI) to allow the distinction of the basic functional relations between environment and $\mathrm{B}$ from those between environment and HI. The crop yield is given by;

$$
Y=B \times H I
$$

where $Y$ is yield and $H I$ is the harvest index.

The overall water balance can be estimated by the following equations:

$$
\begin{gathered}
R+N I R=E T+R O+D P+\triangle S \\
R=R I+R O \\
N I R+R I=E T+D P+\triangle S
\end{gathered}
$$

where $R$ is the rainfall, $N I R$ is the net irrigation requirement, $E T$ is the evapotranspiration, $R O$ is the runoff,
$D P$ is the deep percolation, $\Delta S$ is the change in storage and $R I$ is the infiltration from rainfall. The rainfall becomes either infiltration or runoff. The infiltrated and irrigated water will be stored in the root zone and lost through evapotranspiration and deep percolation. Despite capillary rise of water being a factor on a daily scale, for 30 year means it has been ignored since there is no known contribution from groundwater in the study area. Lateral contributions have also been ignored.

AquaCrop model has recently been parameterized and calibrated for several crops, and validated against experimental data obtained either in other locations or in other years. In northern Ethiopia, AquaCrop simulated and observed values (soil water, biomass, yield, canopy cover) of Teff (a cereal crop in Ethiopia) showed moderately high correlation $\left(\mathrm{R}^{2}>0.95\right)$ under optimal water stress conditions (Araya et al., 2010). In the Mediterranean environments of North Syria the AquaCrop model was also tested using recorded data resulting in accurate prediction of ET (error $<13 \%$ ) and predicted yield values within $10 \%$ of measured values under a full irrigation regime. The model also closely predicted the trend in total soil water (Farahani et al., 2009). The most extensive efforts on calibration and validation of AquaCrop have been carried out in maize and the model is suited for prospective studies of future climate change (Steduto et al., 2009).

A detailed AquaCrop model description is available in Raes et al. (2010) and Chung (2010). Due to model and data limitations, effects of pests and diseases, availability of water for irrigation, availability of nutrients, socioeconomic factors and possible changes in crop sowingmaturity duration in the future were not considered. Crop response was simulated under full irrigation for the baseline and future scenarios.

\section{Model inputs and outputs}

Input parameters for the AquaCrop model include crop, soil, irrigation and cultural management. Output files include crop growth, soil water balance, irrigation requirement, biomass production, yield, and water productivity. More detailed information can be found in Chung (2010) and in 
user manual (Raes et al., 2010). A variety of hybrid and open pollinated maize varieties with different growing season lengths can be grown in Zimbabwe. A set of conservative parameters calibrated and validated for maize and considered applicable to a wide range of conditions and not specific to a given maize cultivar were used as shown in Tables 1 and 2. Crop growth and development were set to be described in calendar time. All the crop characteristics and basic parameter values fell in the range recommended in the user manual. Evaporation from a fully wet soil surface is inversely proportional to the canopy cover and the proportionality factor $\left(K_{e}\right)$ is at its maximum when the soil surface is fully wet and unshaded and it decreases as the canopy develops. Likewise, crop transpiration from a well watered soil is proportional to the effective canopy cover. The proportional factor $\left(K_{c b}\right)$ is at its maximum when the crop cover is complete and approximately equivalent to the basal crop coefficient at mid season. Table 2 shows the basic parameters used in this study. The Penman-Monteith equation was used to compute reference $E T$.

Although the climate input can be daily, decadal, or monthly date, the model simulates using daily time step.

Table 1 Model input information

\begin{tabular}{l||l}
\hline Parameter & Description \\
\hline Soil & Deep loamy soil \\
\hline Crop (maize) & $\begin{array}{l}\text { Zea Mays L., matures in } 135 \text { calendar days (22 October to 7 } \\
\text { March), 75,000 plants/ha }\end{array}$ \\
\hline Climate data & $\begin{array}{l}\text { Rainfall, } \mathrm{ET}_{0}, \text { maximum and minimum air temperatures, and } \\
\text { the mean } \mathrm{CO}_{2} \text { concentration in the bulk atmosphere. } \\
\text { (Daily, decadal, or monthly data are acceptable) }\end{array}$ \\
\hline Irrigation & Full irrigation, starts at $50 \%$ allowable depletion \\
\hline
\end{tabular}

Table 2 Basic parameter values used in the simulations

\begin{tabular}{c|l|c|c}
\hline Parameter & \multicolumn{1}{|c|}{ Description } & Unit & Value \\
\hline \hline $\mathrm{WP}^{*}$ & Normalized water productivity & $\mathrm{gm}^{-2}$ & 33.7 \\
\hline $\mathrm{HI}_{0}$ & Reference Harvest index & $\%$ & 50 \\
\hline $\mathrm{T}_{\text {base }}$ & $\begin{array}{l}\text { Minimum air temperature below which } \\
\text { pollination starts to fail }\end{array}$ & ${ }^{\circ} \mathrm{C}$ & 10 \\
\hline $\mathrm{T}_{\text {upper }}$ & $\begin{array}{l}\text { Maximum air temperature below which } \\
\text { pollination starts to fail }\end{array}$ & ${ }^{\circ} \mathrm{C}$ & 45 \\
\hline $\mathrm{K}_{\mathrm{e}}$ & Evaporation coefficient (initial value) & - & 1.10 \\
\hline $\mathrm{K}_{\mathrm{cb}}$ & Transpiration coefficient (maximum value) & - & 1.03 \\
\hline
\end{tabular}

A daily soil water balance keeps track of the incoming and outgoing water fluxes at the boundaries and of the stored soil water in the root zone.

\section{Results and Discussion}

\section{Changes in Agro climate}

Fig. 4 shows the comparison of predicted parameter values for A2 and B2 scenarios for the northern and southern regions for growing season. The mean annual temperature averaged across the northern region was $21.2{ }^{\circ} \mathrm{C}$ for the baseline period and projected to increase by $1.5^{\circ} \mathrm{C}$ (2020s A2), $1.6^{\circ} \mathrm{C}$ (2020s B2), $3.2^{\circ} \mathrm{C}$ (2050s A2), $2.2{ }^{\circ} \mathrm{C}(2050 \mathrm{~s} \mathrm{~B} 2), 5.0{ }^{\circ} \mathrm{C}(2080 \mathrm{~s} \mathrm{~A})$ and $4.0{ }^{\circ} \mathrm{C}(2080 \mathrm{~s}$ B2). The mean for the southern region was $20.1^{\circ} \mathrm{C}$ and the temperature is projected to increase by $1.7^{\circ} \mathrm{C}$ (2020s A2), $1.7{ }^{\circ} \mathrm{C}$ (2020s B2), $3.1{ }^{\circ} \mathrm{C}$ (2050s A2), $2.4{ }^{\circ} \mathrm{C}(2050 \mathrm{~s}$ B2), $5.2{ }^{\circ} \mathrm{C}$ (2080s A2) and $4.1{ }^{\circ} \mathrm{C}$ (2080s B2). The analysis reveals that in all scenarios, temperature has an increasing trend. Maximum temperatures were predicted to increase at a faster rate than minimum temperatures as shown in Fig. 4 (a) and (b).

Fig. 4 (c) shows the predicted rainfall during the growing season (22 October to 7 March) for the baseline and future scenarios. Average rainfall decreases by $9 \%$ (2020s A2), $6 \%$ (2020s B2), $3 \%$ (2050s A2), 2 \% (2080s B2) and increases by $1 \%(2050 \mathrm{~s}$ B2) and $6 \%$ (2080s A2), in comparison to the 30 year baseline (1970s) average of $653 \mathrm{~mm}$ for the northern region. Average rainfall decreases by $13 \%$ (2020s A2), $12 \%$ (2020s B2), $10 \%$ (2050s A2), $5 \%$ (2050s B2), $10 \%$ (2080s A2) and $9 \%$ (2080s B2) in comparison to a 30 year baseline (1970s) average of $495 \mathrm{~mm}$ for the southern region. As outlined in the study area description, rainfall is lower in the southern region.

\section{Changes in water use and yields}

A summary of the results of the model simulations carried out for the baseline and future scenarios for simulated parameters i.e. rainfall, infiltration, runoff, deep percolation, evaporation, transpiration, change in storage, biomass, yield, water productivity, and the net irrigation 


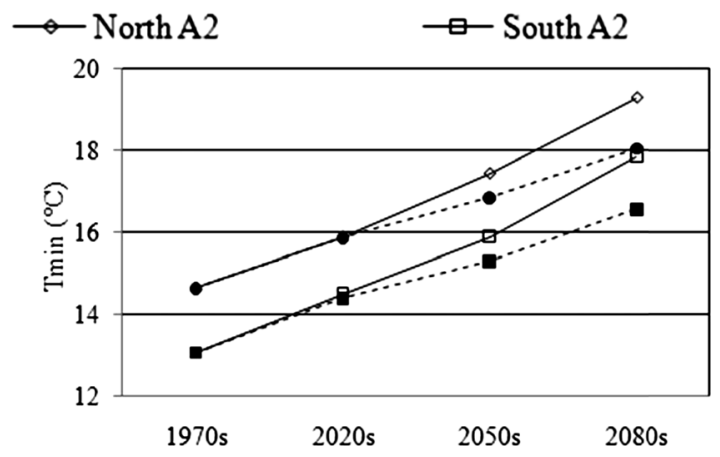

(a) Minimum temperature

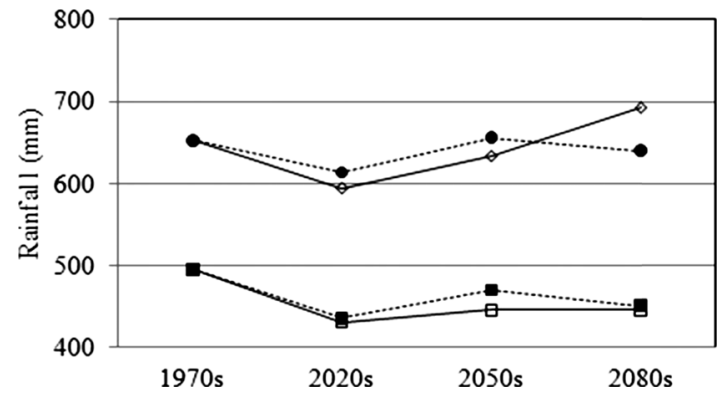

(c) Growing season rainfall

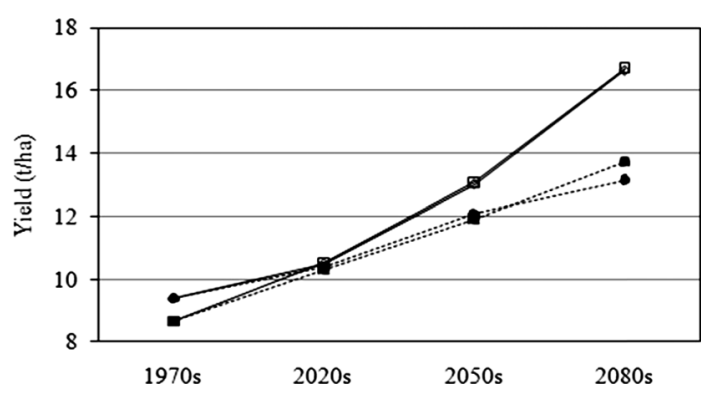

(e) Grain yield

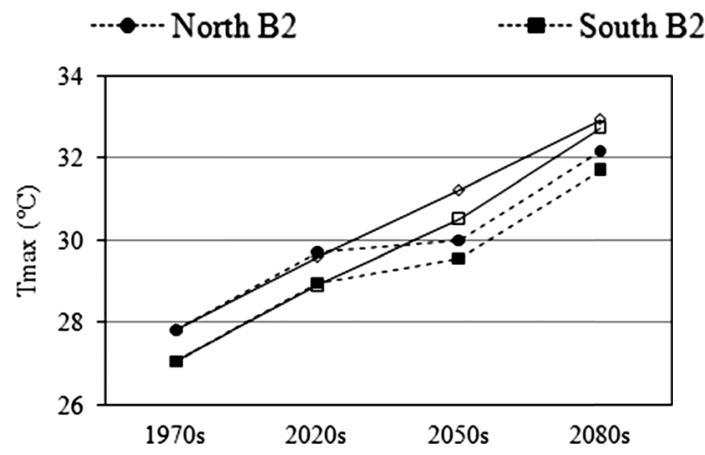

(b) Maximum temperature

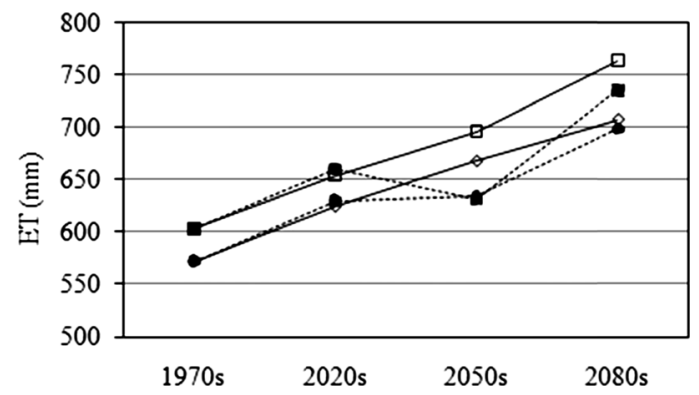

(d) Growing season ET

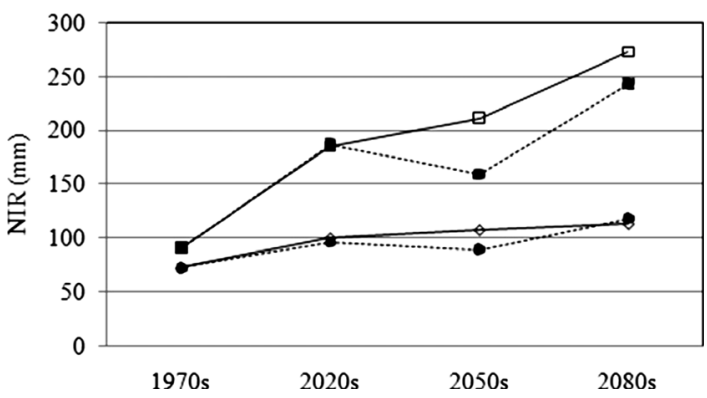

(f) Net Irrigation water requirement

Fig. 4 Comparison of predicted parameter values for A2 and B2 scenarios for the northern and southern regions

water requirement (NIR) are presented for in Tables 3 and 4 . Values in Table 3 are presented as an average depth of water over the northern and southern regions of Zimbabwe. Absolute changes in runoff for the simulated scenarios in the northern region are closely related to changes in precipitation. In the southern region however runoff is not expected for all scenarios. The simulated values were well matched with the water balance equation (4). The low to nil simulated runoff amounts are caused by the fact that AquaCrop distributes monthly rainfall into equal daily amounts.

Fig. 4(e) shows the predicted trend in maize yield in spite of the losses due to temperature stress. Proportional yield increases are shown to be higher for the southern region in comparison to those of the northern region. For each region the A2 scenario gives a higher yield as a result of the higher $\mathrm{CO}_{2}$ concentrations.

The trend in NIR is shown in Fig. 4(f). For the southern region, NIR was predicted to increase by $167 \%$ (2080s B2), $200 \%$ (A2) and for the northern region $56 \%$ (2080s A2) and $63 \%$ (2080s B2). NIR has an inverse relationship with rainfall and a direct relationship with ET. The NIR is predicted to show a slight decreasing/slower increasing trend towards the 2050s. This can be attributed to the 
Nkomozepi Temba $\cdot$ Chung, Sang-Ok

Table 3 Simulated water balance for the baseline and future scenarios (unit: $\mathrm{mm}$ )

\begin{tabular}{|c|c|c|c|c|c|c|c|c|c|c|}
\hline Region & Scenario & Rainfall & Runoff & $\mathrm{RI}$ & $\mathrm{DP}$ & Evaporation & Transpiration & ET & NRR & $\Delta S$ \\
\hline \multirow{7}{*}{ Northern } & Baseline & 660.0 & 1.3 & 658.7 & 158.7 & 230.1 & 342.2 & 572.3 & 72.5 & 0.2 \\
\hline & 2020s A2 & 600.8 & 0.2 & 600.6 & 77.0 & 248.3 & 376.2 & 624.5 & 100.1 & -0.8 \\
\hline & 2020s B2 & 620.4 & 0.4 & 620.0 & 86.6 & 247.0 & 383.1 & 630.1 & 95.9 & -0.8 \\
\hline & 2050s A2 & 640.3 & 0.8 & 639.5 & 80.9 & 261.0 & 406.5 & 667.5 & 107.7 & -1.2 \\
\hline & 2050s B2 & 663.3 & 1.4 & 661.9 & 117.8 & 249.8 & 384.0 & 633.8 & 89.4 & -0.3 \\
\hline & 2080s A2 & 699.7 & 3.0 & 696.7 & 103.7 & 277.4 & 429.8 & 707.2 & 113.1 & -1.1 \\
\hline & 2080s B2 & 646.8 & 0.9 & 645.9 & 66.8 & 272.5 & 426.2 & 698.7 & 118.1 & -1.5 \\
\hline \multirow{7}{*}{ Southern } & Baseline & 501.8 & 0 & 501.8 & 1.3 & 228.3 & 374.9 & 603.2 & 90.8 & -11.9 \\
\hline & 2020s A2 & 436.5 & 0 & 436.5 & 1.1 & 244.3 & 409.9 & 654.2 & 184.8 & -34.0 \\
\hline & 2020s B2 & 441.4 & 0 & 441.6 & 1.1 & 246.7 & 413.7 & 660.4 & 187.0 & -33.1 \\
\hline & 2050s A2 & 451.4 & 0 & 451.4 & 1.2 & 259.5 & 436.4 & 695.9 & 211.1 & -34.6 \\
\hline & 2050s B2 & 476.7 & 0 & 476.7 & 8.3 & 230.6 & 400.7 & 631.3 & 159.2 & -3.7 \\
\hline & 2080s A2 & 451.6 & 0 & 451.6 & 1.2 & 281.6 & 481.9 & 763.5 & 272.5 & -40.6 \\
\hline & 2080s B2 & 456.6 & 0 & 456.6 & 1.2 & 272.5 & 462.8 & 735.3 & 242.8 & -37.1 \\
\hline
\end{tabular}

GCM's predicted increases in rainfall and humidity which in turn decrease the evaporative demand. The phenomenon is more apparent in the B2 scenario where lower temperatures are expected than for the A2 scenario. Surface temperatures have a direct relationship with sensible and latent heat exchange processes that govern ET. NIR in the northern region is therefore less than that in the southern region. The trends in the actual ET are shown in Fig. 4(d). The actual ET is generally increasing for the A2 scenario for both regions but decreasing towards the 2050s for the B2 scenarios. Transpiration has an increasing trend that is higher than evaporation.

Average yields are projected to increase for irrigated maize under both the $\mathrm{A} 2$ and $\mathrm{B} 2$ scenarios for all time slices because the direct effect of $\mathrm{CO}_{2}$ is included. The increase in yield is simulated to be highest under the A2 scenario. As shown in Tables 3 and 4, the southern region is predicted to experience higher proportional increases in yield. The southern region is generally drier than the northern region. It was shown that despite it being a $\mathrm{C}_{4}$ plant, maize will significantly sense and respond to higher atmospheric $\mathrm{CO}_{2}$ concentrations through increased photosynthesis and reduced stomatal conductance. Changes initiated by increases in atmospheric $\mathrm{CO}_{2}$ concentration following a precise signal transduction pathway collectively depolarize the membrane potential of guard cells and cause stomatal closure. This study shows results similar to Li
Table 4 Simulated production and water productivity for the baseline and future scenarios

\begin{tabular}{c|c|c|c|c|c|c|c}
\hline \multirow{3}{*}{ Region } & \multirow{2}{*}{ Scenario } & \multicolumn{3}{|c|}{ Production (t/ha) } & \multicolumn{3}{c}{ Water productivity $\left(\mathrm{kg} / \mathrm{m}^{3}\right)$} \\
\cline { 3 - 8 } & & Biomass & Grain & $\%$ increase & Biomass & Grain & $\%$ increase \\
\hline \hline \multirow{5}{*}{ Northern } & Baseline & 26.1 & 9.4 & - & 5.00 & 1.80 & - \\
\cline { 2 - 8 } & 2020s A2 & 29.1 & 10.5 & 12 & 5.11 & 1.84 & 2 \\
\cline { 2 - 8 } & 2020s B2 & 28.8 & 10.4 & 11 & 5.02 & 1.81 & 1 \\
\cline { 2 - 8 } & 2050s A2 & 36.2 & 13.0 & 39 & 5.95 & 2.14 & 19 \\
\cline { 2 - 8 } & 2050s B2 & 33.6 & 12.1 & 29 & 5.81 & 2.09 & 16 \\
\cline { 2 - 8 } & 2080s A2 & 46.2 & 16.6 & 77 & 7.18 & 2.58 & 43 \\
\cline { 2 - 8 } & 2080s B2 & 36.5 & 13.2 & 40 & 5.74 & 2.07 & 15 \\
\hline \multirow{5}{*}{ Southern } & Baseline & 24.0 & 8.7 & - & 4.36 & 1.58 & - \\
\cline { 2 - 8 } & 2020sA2 & 29.1 & 10.5 & 22 & 4.90 & 1.77 & 12 \\
\cline { 2 - 8 } & 2020sB2 & 28.6 & 10.3 & 19 & 4.75 & 1.72 & 09 \\
\cline { 2 - 8 } & 2050s A2 & 36.2 & 13.1 & 51 & 5.72 & 2.07 & 31 \\
\cline { 2 - 8 } & 2050s B2 & 33.0 & 11.9 & 38 & 5.62 & 2.03 & 28 \\
\cline { 2 - 8 } & 2080s A2 & 46.2 & 16.7 & 93 & 6.67 & 2.41 & 53 \\
\cline { 2 - 7 } & 2080s B2 & 38.0 & 13.7 & 59 & 5.69 & 2.05 & 30 \\
\hline
\end{tabular}

et al. (2011) where yield was predicted to increase by $10.7 \%$ under a climate change scenario where temperature increases $1.5{ }^{\circ} \mathrm{C}$.

The water productivity was simulated to increase for the future scenarios as expected since there is less deep percolation compared to the baseline in the northern region. The $\%$ increase of water productivity for the southern region was higher than northern region. Both the water productivity and $\%$ increase were higher for the A2 than 
for the B2 scenario. This is in agreement with the results from a growth chamber study by Chun et al. (2011) that suggested that under elevated $\mathrm{CO}_{2}$ concentrations maize plants have higher water use efficiency.

\section{Limitations}

One of the limitations of the AquaCrop model is that simulation runs use input data from a single point/site whilst impact assessments cover relatively large areas. Parameterizations and calibrations in AquaCrop are therefore not easily extended from site to catchment/regional scale. AquaCrop application in this study is also limited by daily data unavailability. AquaCrop averages monthly means into equal daily averages for daily water balance analyses thereby causing inaccuracy in the output data, especially the rainfall data. The results of this study could have limited utility because future changes could be outside the range of the historical climatic variation used to calibrate them. Lastly, this study has used simulations for potential yields, so actual yields could decrease if appropriate resources and management such as crop choice, planting time, soil cultivation and crop cultural practices (weeding, planting density, fertilization) water conservation and irrigation are not made available.

\section{Conclusion}

Predictions of the water balance and yield for the future are essential for implementing risk management strategies at national level in response to climate change. In this study, downscaled outputs from the HadCM3 were used to compute the water balance and yield for the baseline and future scenarios for irrigated maize in the southern and northern regions of Zimbabwe. The potential yields are expected to increase for all future scenarios for both regions. Yields were simulated to increase by up to $93 \%$ (2080s A2) in the southern region. The water productivity were predicted to increase significantly by up to $53 \%$ for the future scenarios. Water productivity was simulated to be higher in the northern region for all scenarios but the change ratio is higher in the southern region. It was shown that climate change could have a dramatic effect on the water balance. The water balance will significantly shift and more water will be taken up by ET and less will be lost as runoff and deep percolation. The net irrigation water requirement is also expected to increase hence future actual yields will depend upon resource, management and water availability.

\section{REFERENCES}

1. Ahn, S. R., M. J. Park, G. A. Park and S. J. Kim, 2009. Assessing future climate change impact on hydrologic components of Gyeongancheon watershed. Journal of Korea Water Resources Association 42(1): 33-50 (in Korean).

2. Araya, A., S. D. Keesstra, L. Stroosnijder, 2010. Simulating yield response to water of Teff (Eragrostis tef) with FAO's AquaCrop model. Field Crops Research 116: 196-204.

3. Chun, J. A., Q. Wang, D. Timlin, D. Fleisher and V. R. Reddy, 2011. Effect of elevated carbon dioxide and water stress on gas exchange and water use efficiency in corn. Agricultural and Forest Meteorology 151: $378-384$

4. Chung, S. O., 2010. Simulating Evapotranspiration and Yield responses of Rice to Climate Change using FAOAquaCrop. Journal of the Korean Society of Agricultural Engineers 52(3): 57-64 (in Korean).

5. Chung, S. -O., J. A. Rodriguez-Diaz, E. K. Weatherhead and J. W Knox, 2011. Climate change impacts on water for irrigating paddy rice in South Korea. Irrigation and drainage 60(2): 263-273.

6. Diaz-Nieto, J., and R. L. Wilby, 2005. A Comparison of statistical downscaling and Climate change factor methods: Impacts on Low flows in the river Thames, United Kingdom. Climate Change 69: 245-268.

7. Doorenbos, J., and A.H. Kassam, 1979. Yield response to water. Irrigation and Drainage Paper No. 33. FAO, Rome, Italy.

8. Farahani, H. J., G. Izzi and T. Y. Oweis, 2009. Parameterization and evaluation of the AquaCrop model for full and deficit irrigated cotton. Agronomy Journal 101: 469-476.

9. Gordon, C., C. Cooper, C. A. Senior, H. Banks, J. M. 
Gregory, T. C. Johns, J. F. B. Mitchell and R. A. Wood, 2000. The simulation of SST, sea ice extents and ocean heat transports in a version of the Hadley Centre coupled model without flux adjustments. Climate Dynamics 16: 147-168.

10. Hsiao, T. C., L. K. Heng, P. Studeto, B. Rojas-Lara, D. Raes and E. Fereres, 2009. AquaCrop-The FAO crop model to simulate yield response to water: III. Parameterization and testing for maize. Agronomy Journal 101: 469-476.

11. Intergovernmental Panel on Climate Change (IPCC), 2001. Data distribution centre. http://www.ipcc-data.org/ ancilliary/tar-bern.txt accessed on 28 Sep. 2010.

12. Li, X., T. Takahashi, N. Suzuki, H. M. Kaiser, 2011. The impact of climate change on maize yields in the United States and China. Agricultural Systems. doi: 10.1016/ j.agsy.2010.12.006

13. New, M., D. Lister, M. Hulme and I. Makin, 2002. A high resolution data set of surface climate over global land areas. Climate Research 21: 1-25.

14. Nkomozepi, T., and S. O. Chung, 2011. Assessing the effects of Climate Change on irrigation water requirements for corn in Zimbabwe. Journal of the Korean Society of Agricultural Engineers 53(1): 47-55.
15. Phillips, J. G., M. A. Cane and C. Rosenzweig, 1998. ENSO, seasonal rainfall patterns and simulated maize yield variability in Zimbabwe. Agricultural and Forest Meteorology 90: 39-50.

16. Raes, D., P. Steduto, T. C. Hsiao and E. Fereres, 2010. AquaCrop reference manual, AquaCrop version 3.1, FAO, Land and Water Division, Rome, Italy.

17. Steduto, P., D. Raes, T. C. Hsia, E. Fereres, L. K. Heng, T. A. Howell, S. R. Evett, B. A. Rojas-Lara, H. J. Farahani, G. Izzi, T. Y. Oweist, S. P. Wani, J. Hoogeveen and S. Geerts, 2009. Concepts and applications of AquaCrop: the FAO crop productivity model. http://ddr.nal.usda.gov/bitstream/10113/37297/1/ IND44289150.pdf accessed on 12 Dec. 2010.

18. Unganai, L. S., and F. N. Kogan, 1998. Drought Monitoring and Corn Yield Estimation in Southern Africa from AVHRR Data. Remote sensing Environment 63: 219-232.

19. Wurzel, P., 1987. Hydrology in Zimbabwe - the past and the future. Water for the Future: Hydrology in Perspective. In Proc. Rome Symposium. 